March 2013, Volume 3, No. 1 Pages (123 - 150)

\title{
Developing Research Plan for Department of Curricula and Physical Education Teaching Methods in Alexandria, Analytical Study of Problems Associated with Learning and Teaching Process as per Total Quality Academic Standards
}

\author{
Neveen Mahmoud Farouk Haridi*, Hanan Ahmed Murad**, Iman Mahmoud ElSharif**
}

\author{
* Lecturer, Department of Curriculum and Physical Education Teaching Methods, Faculty of Physical \\ Education for Girls, Alexandria University. \\ ** Lecturer, Department of Educational, psychological and social sciences, Faculty of Physical Education \\ for Girls , Alexandria University.
}

\section{Introduction:}

$\mathrm{O}$ ur contemporary world is facing radical shifts and changes in all fields. We are living in an era where human knowledge flowed, with great achievements in science, culture and technology fields. Thus affect life shape and future outlines. There is no alternative choice but considering reasons for overall development as permitted by capabilities. Now we share one world life, contended with knowledge and information, with numerous databases, networks. Due to this; education/work and work/technology relationships heightened. Therefore third millennium teacher had to struggle to take place in the society by maximizing educational and research output of educational institutions, and improving its return to achieve total development.

Good education is that who embodied total quality features in its inputs, including students, teachers, administrators, programs, curricula, books, content, teaching methods, evaluation processes, educational buildings and general environment. As all inputs contribute in improving educational outcomes, which is represented in graduate capable to be familiar with various knowledge, information and skills that can be applied in his career. (Mohamed sabry Elhot, Nahed Aly, 2007: 25), (Mohamed hassouna, 2003: 3)

Therefore many higher education institutions in different world countries adopted the concept of quality as a work for several reasons. One of the most important reason is to meet community needs from specialized staff capable of competition to deal efficiently with the era changes which is characterized by revolution of knowledge and technology. (Hassan Beblawi, Roushdy Teima 2000: 33, 34) (Amin Fahmy, 2004: 23)

Faculty of Physical Education for Girls in Alexandria is one of the educational institutions specialized in qualifying leaders to work in field of physical education and sport. Faculty mission is to publish, apply and develop knowledge to prepare professional staff with high quality scientific level as per recognized scientific standards in fields of education, training, recreation and sport management as appropriate with the nature of work and society needs in future stage.

Based on objectives of Education Section, that managed by Department of Curricula and Physical Education Teaching Methods. These objectives are enriching academic and intellectual environment to improve educational process; prepare professional physical education teacher to be responsible member in community; able to work in all different educational institutions. Also within these objectives is commitment to excellence in teaching and learning by providing high quality syllabuses, which reflect latest information in field of curricula and physical education teaching methods. As well as innovative research and scientific studies which work to find positive solutions in the field of teaching and learning Physical Education. Also preparations of qualified graduates have skills 
of scientific research and efficiency in using these skills to identify school sports' problems.

Hence, educational research role is clear. Educational studies and references confirmed that educational research is essential in development of education system in terms of inputs and outputs in accordance with total quality requirements. (Ghalib Freihat, 2008: 14)

Perhaps this called these institutions managers to develop research plans based on studying problems surrounding educational process. That is aiming to achieve development in these institutions, within the framework of higher education institutions development. All work in light of universality principle, not just on the national level. (Rushdie Teima 2008: 36), (Sawsan Shaker, Mohamed Awad, 2008: 13)

On the basis of application of total quality in all sections and scientific departments in the faculty, it was necessary that Department of Curricula and Physical Education Teaching Methods conduct self- evaluation and total examination for all problems associated with teaching and learning process. This evaluation done through studying factors affect faculty internal environment. Starting from the admission of students in first and second grade as preliminary phase; where they taught basics of sports activities and what it is include from curricula and syllabuses where all faculty departments contribute in preparing. Examine appropriateness of these syllabuses with students needs. As well as studying curricula and syllabuses in third and fourth grade in Education Division, which called sports activities and teaching methods curricula in terms of syllabuses, teaching methods, tools, evaluation. Also studying factors affect external environment of beneficiaries from physical education teachers, Physical Education guiders about physical education curricula in different educational stages. This includes human and material resources. As well as school sports activities, like internal and external activity, scouts, girl scouts, camps, school parties, sports and culture shows. All this in order to determine internal and external environment strengths to promote; problems and weaknesses to be addressed through a research plan for Department of Curricula and Physical Education Teaching Methods. This plan to be developed on sound scientific basis to guide researchers from faculty members and outsiders preparing for master's and doctoral degrees, to present researches define positive solutions to problems previously identified in the field of curricula and physical education teaching methods in different educational institutions at all levels and categories.

\section{Research Problem}

Researchers noted - in recent period - that PostGraduate committee permanently emphasizes the necessity of modernity for proposed researches (master, $\mathrm{PhD}$ ) and that topics should be of practical value to community. This is in agreement with scientific research strategy for Oxford University which States:" university is committed to make significant contributions to society, regionally, nationally and internationally, through the its scientific research" (University of oxford 2008: 13).

Many studies shown interest in problems associated with teaching and learning process in physical education, for example, but not limited to, Mahmoud Abu Enein (1990), Meln Chuk (1990), Suhair Almohandes (1991), keith Elizabeth (1991), Saeed Khalil (1992),Susan A.capel (1993), Mahmoud Samy (1993), Arlen Cary Blix (1994), Iman Sadek (1995), Douthitt Vicki (1995), Magdi Sadek (1995), Jeane Kentel (1996) , Murad Saleh (1997), Iqbal kamel et al (1998)), Lund Mark (1998), Ayman al-Shaer (1999), Angorla Scott (2002), Wafaa Elsaify(2002) , Iman Alharony and Kausar Abdul Majid (2003), Iman Abdullah (2004), Ihab Abd Allah (2007), Alaa Eddin Ibrahim and Hany Said (2007).

Results of these studies confirmed that there are still many problems associated with teaching and learning process in Physical Education, whether (professional, human and other resource, teacher relationship with learners and his colleagues, technical guidance, school administration), which need for more research and study.

None of these previous studies concerned with developing research plan to address this problems or to associate scientific research issues with society needs. Didi Griffioen study emphasized the necessity of selecting research topics should be applicable or utilizable and its 
its results should be useful for society (Didi Griffioen, 2012: 17)

Researchers noted that (2005 -2009) Five-Year research plan for Department of Curricula and Physical Education Teaching methods contained common topics. Topics have not been updated for long time. Also they do not in agreement with quality standards fields for post-graduate studies that the departments seek to achieve. These fields as accredited by National Authority for Quality Assurance and accreditation (2010) are (learning, scientific research, community service, management aspects and skills development).

Asking post-graduate students and researchers about benefiting from research plan, most of them confirmed that they do not use research plan because it is out of date, not in conformity with outside faculty society requirements. Through a personal interview with the Vice Dean for Post-Graduate Studies and members of the Post-Graduate Studies Committee; all agreed that there is need to develop a research plan for the department in accordance with quality academic standards. That is to encourage innovation in scientific research and to keep pace with outside society requirements. Department of Curricula and Physical Education Teaching Methods is one of the key and important faculty sections. As there is integration between this department and other faculty departments, which is clear from student preparation syllabuses starting from faculty joining to graduation. Thereby this study aimed to develop research plan for department of curricula and physical education teaching methods in Alexandria, through analytical study of problems associated with learning and Table (1) Study Sample teaching process as per total quality academic standards

\section{Study Objective}

This study aims to develop research plan for post graduate researchers at department of Curricula and Physical Education Teaching Methods in Faculty of Physical Education for Girls, Alexandria.

\section{Study Query}

As per study objective following query can be set

What is the suggested research plan for post graduate researchers at department of Curricula and Physical Education Teaching Methods in Faculty of Physical Education for Girls, Alexandria?

\section{Study Procedures}

1 - Study approach: descriptive survey approach was used as it relevance to this study nature.

2 - Study Society: Included:

a- Faculty staff members in various scientific departments

b- Preliminary phase students (first and second grades) for the academic year 2009/2010

c- Specialization phase Students (third and fourth grades, Education Division) for the academic year 2009/2010.

d- Guiders and teachers in Middle Education Department, Alexandria.

3- Study sample: The sample selected randomly as shown in the table (1) and figure (1)

\begin{tabular}{||l|l|l|l|l||}
\hline Category Society & $\begin{array}{l}\text { Study } \\
\text { Sample }\end{array}$ & $\begin{array}{l}\text { Pilot Study } \\
\text { sample }\end{array}$ & Excluded \\
\hline Faculty staff members & 95 & 70 & 25 & - \\
\hline $\begin{array}{l}\text { Guiders and teachers in Middle Education } \\
\text { Department }\end{array}$ & 152 & 75 & 25 & 52 \\
\hline First grade students & 195 & 170 & 25 & - \\
\hline Second grade students & 195 & 170 & 25 & - \\
\hline Third grade students & 68 & 43 & 25 & - \\
\hline Forth grade students & 112 & 87 & 25 & - \\
\hline
\end{tabular}




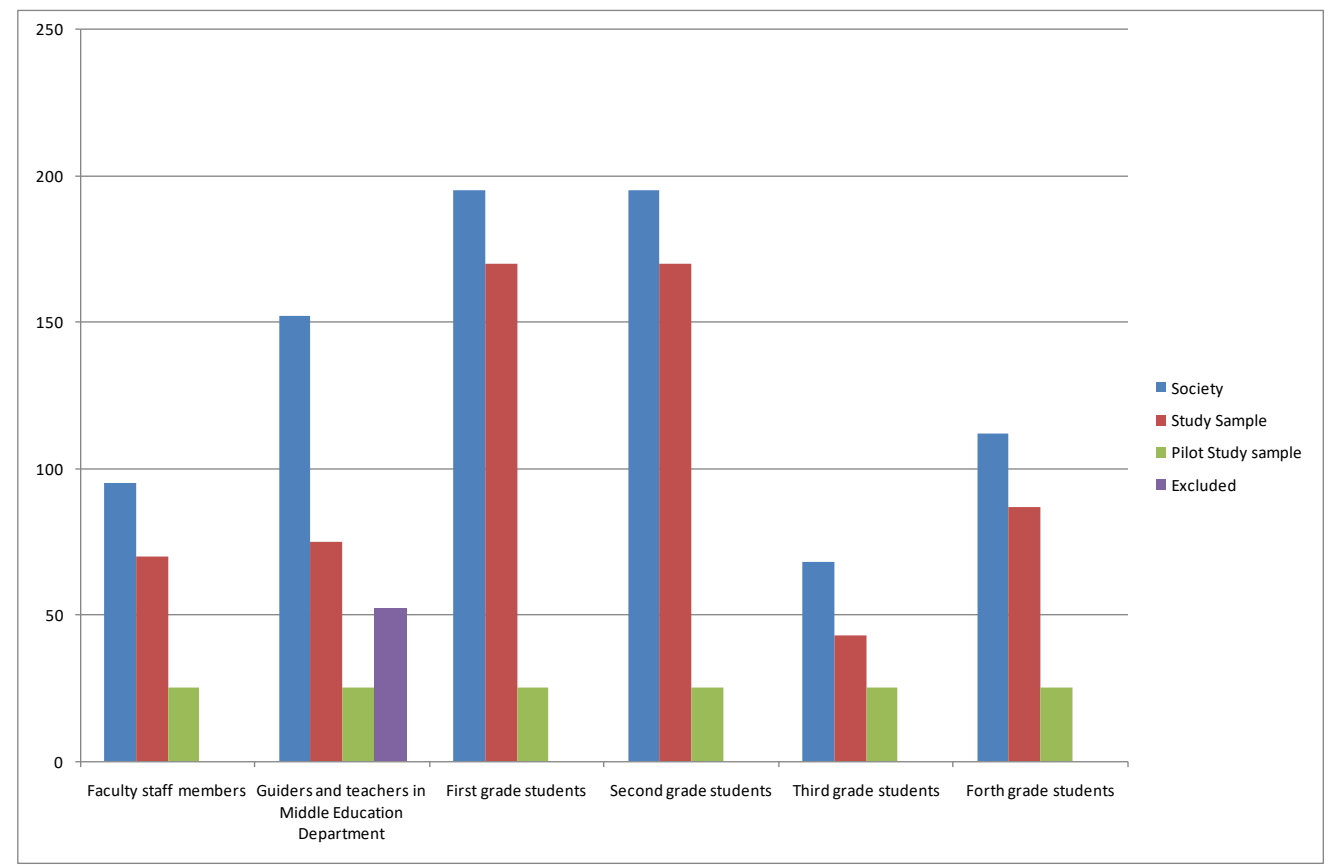

Figure (1) Study sample

\section{Study Tools:}

\section{Researchers prepared the following tools:}

1- Questionnaire form for Faculty staff, Department of Curricula and Physical Education Teaching Methods and other scientific departments (Sport Training and movement sciences, Recreation, Health Sciences, Educational, Psychological and Social Sciences and Sports Management). This questionnaire uses an open-answer question about problems related to teaching sports activities syllabuses in preliminary phase and specialized phase (education section). Staff other than Department of Curricula and Physical Education Teaching Methods was included considering that some of the cultural, educational and physical subjects they teach and contribute in preparation of the student/teacher. (Prepared by the researchers)

2- Questionnaire form for Faculty students (preliminary phase; i.e. first and second grades) in the year (2009/2010) about problems they are facing in curricula and physical education teaching methods program. (Prepared by the researchers)

3- Questionnaire form for Faculty students (specialization phase; i.e. third and fourth grades) in the year (2009/2010) about problems they are facing in curricula and physical education teaching methods program. (Prepared by the researchers)

4- Questionnaire form for physical education guiders and teachers about school sport problems. (Prepared by the researchers)

In following paragraphs researchers will present these tools and scientific steps that were followed to prepare and standardize them till considered valid for application in its final form.

Questionnaire form for Faculty staff in all departments

The researchers set up an open question for faculty staff members in all departments (70 staff member)

\section{Questionnaire's Objectives}

- Identify problems associated with teaching syllabuses and courses related to other scientific sections. Results to be used to develop a research plan to be analyzed and studied by postgraduate researchers. All staff members interviewed personally.

- Determining the two students questionnaires aspects (preliminary and specialization phases)

The question was: 
- What are the problems associated with teaching sports activities syllabuses in department of Curricula and Physical Education and related courses from other departments to use in developing research plan for the department?

Analysis of answers revealed (62) statement categorized in (6) aspects: (Curricula - teacher learner - school administration - resources technical guidance)

Based on results obtained from this question's answers; researchers prepared two questionnaires for students (preliminary and specialized phase for education section) and one for guiders and teachers

a. Questionnaire form for Faculty students (preliminary phase, i.e. first and second grade ) and (specialization phase; i.e. third and fourth grade (education section) in the year (2009/2010) about problems they are facing in curricula and physical education teaching methods program

1- Questionnaires' objectives
This questionnaire aim to get feedback from students from both preliminary phase and specialization phase (education section) in the academic year 2009/2010 towards the program and syllabuses offered to them in both phases to identify problems and weaknesses that need to be studied. So based on these questionnaires results some proposals and research issues could be suggested to find solution for these problems based on scientific basis to develop the educational process.

2 - Sources of questionnaires aspects:

- Faculty of Physical Education objectives.

- Department of Curricula and Physical Education Teaching Methods objectives.

- Curriculum elements.

- Total quality academic standards.

- The open question questionnaire results.

3 - Determining the two questionnaires' aspects (for students in preliminary and specialization phases - education section): (refer to table 2 and figure 2):

Table (2) Students' (preliminary and specialization phases - education section) questionnaires aspects and statements

\begin{tabular}{|l|l|l|l|}
\hline S & Aspect & $\begin{array}{l}\text { Preliminary phase } \\
\text { questionnaire } \\
\text { statements }\end{array}$ & $\begin{array}{l}\text { Specialization phase } \\
\text { questionnaire } \\
\text { statements }\end{array}$ \\
\hline 1 & Acceptance tests & 3 & 5 \\
\hline 2 & Syllabuses and & 2 & 17 \\
\hline 3 & Teaching methods basics methods teaching & - & 3 \\
\hline 4 & $\begin{array}{l}\text { Evaluation } \\
\text { techniques }\end{array}$ & 6 \\
\hline 5 & $\begin{array}{l}\text { Physical education } \\
\text { methods }\end{array}$ & 9 \\
\hline
\end{tabular}




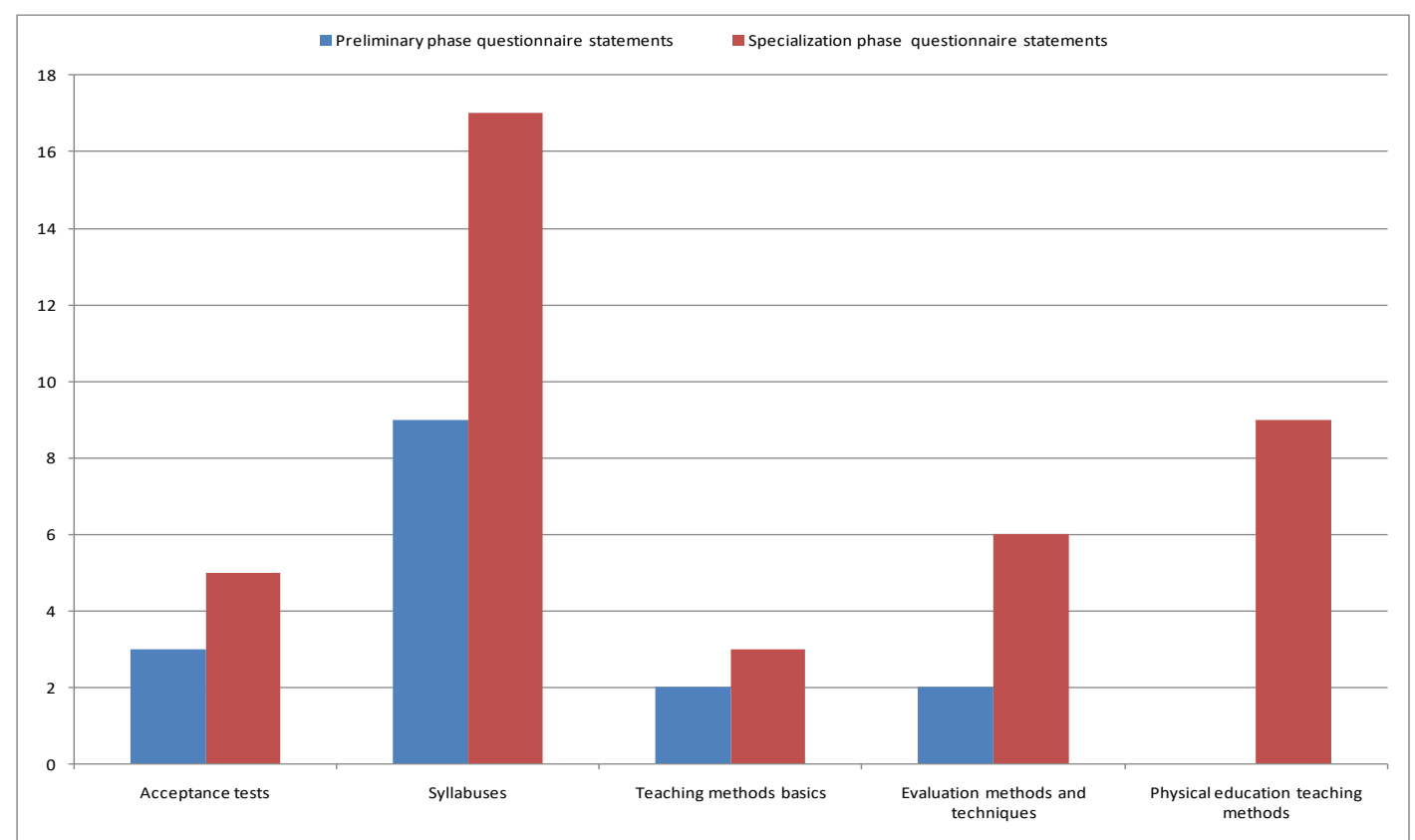

Figure (2) Students' (preliminary and specialization phases - education section) questionnaires aspects and statements

Researchers took into account that each aspect have questions, and questions to be answered by putting $(\checkmark$ ) in three scale answer (yes, to some extent, no) Thus the initial form prepared to be presented to experts.

b. Questionnaire form physical education guiders and teachers about school sport educational and professional problems

\section{1- Questionnaire's objective}

This questionnaire aim is to get feedback from guiders and teachers (beneficiaries) about school sport educational and professional problems, so based on results of this step some proposals and issues could be suggested to be utilized in development of the educational process.

\section{2- Sources of Questionnaire aspects:}

1- Scientific literature and previous studies related to school sport.

2- Views of specialists in field of curricula physical education teaching methods.

3- Open question questionnaire results.

\section{3- Determining questionnaire aspects:}

Questionnaire divided to 7 aspects, researchers developed set of statements for each aspect totaled to (102) statements (table 3 and Figure 3). Researchers considered that these statements should be sequential and in homogeneous groups, also they took into account that statements to be in clear language and does not require a lot of explanation and illustration.

Table (3) Physical education guiders and teachers in educational middle directorate questionnaire aspects and statements

\begin{tabular}{|l|l|l|}
\hline $\mathrm{S}$ & Aspect & No. of statements \\
\hline 1 & Problems associated with curriculum & 10 \\
\hline 2 & Problems associated with teacher & 9 \\
\hline 3 & Problems associated with learner & 10 \\
\hline 4 & Problems associated with technical guidance & 9 \\
\hline 5 & Problems associated with school administration & 9 \\
\hline 6 & Problems associated with resources presentation, evaluation & 34 \\
\hline 7 & $\begin{array}{l}\text { Teacher teaching skills (personal, planning, lesson prete } \\
\text { competencies) }\end{array}$ & \\
\hline
\end{tabular}




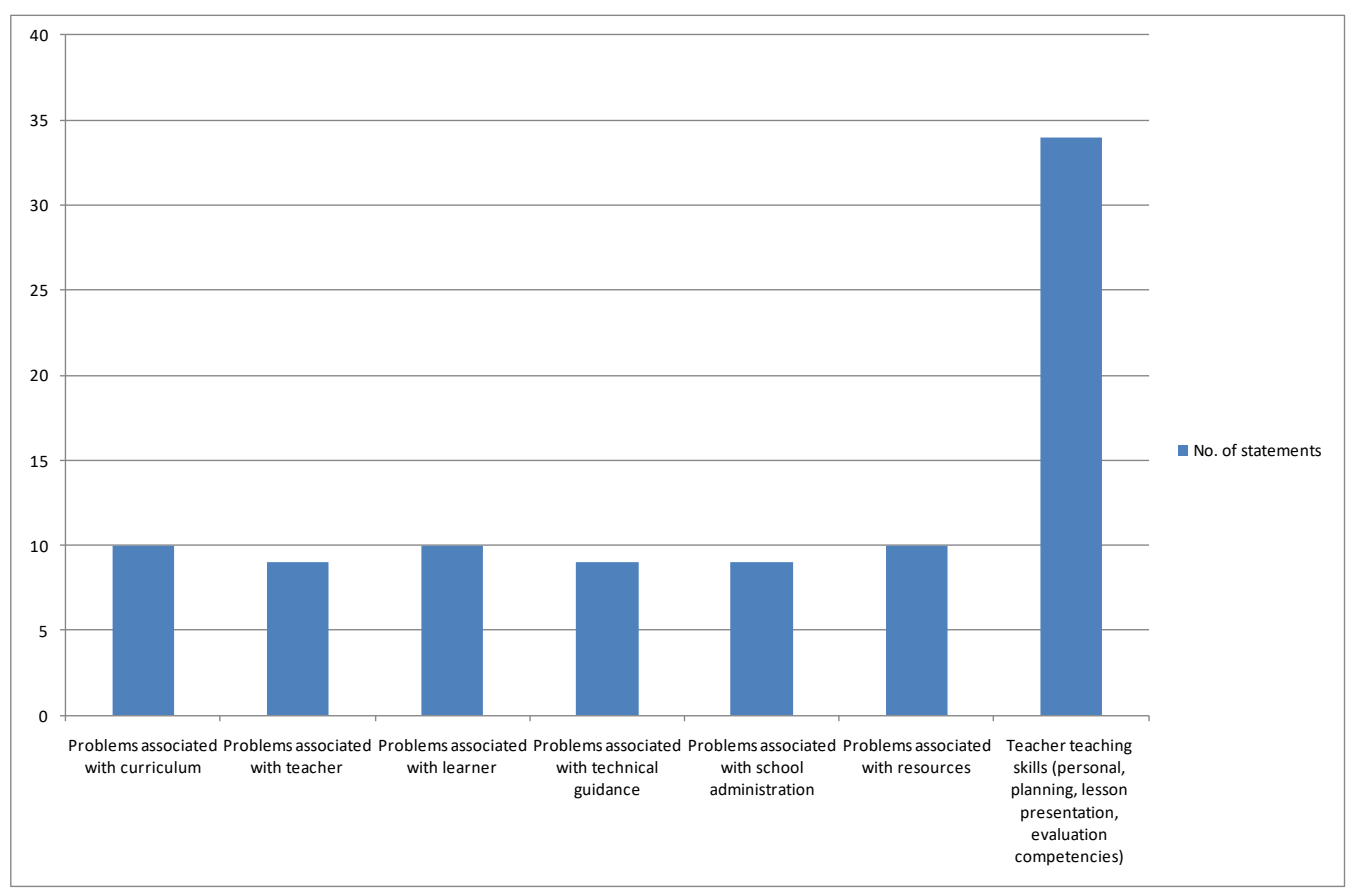

Figure (3) Physical education guiders and teachers in educational middle directorate questionnaire aspects and statements

Questionnaires Standardizing (Faculty staff, students (preliminary and specialization phases - education section), and physical education guiders and teachers questionnaires)

\section{I - Validity:}

To verify questionnaires validity researchers used experts validity by presenting the questionnaires to (9) experts and professionals in curricula and teaching methods all amendments required by experts have been done, questionnaires represented to them, so final forms of them are ready for application.

\section{II - Reliability}

All questionnaires applied to respective pilot study sample and reapplied after one week, for staff member, preliminary and specialization phase students -education section, and physical education guiders and teachers in educational middle directorate Alpha Cronbach reliability factor calculated and found $(0.722,0.838,0.918$ , 0.778) respectively which reveal high reliability to all questionnaires.

\section{Questionnaires application}

After confirmation of questionnaires validity, reliability and suitability for application it has been distributed to respective main study sample in first semester of the academic year (2009-2010).

Statistical methods and factors used:

- mean and standard deviations

- correlation matrix

- Factor analysis using orthogonal rotation with Varimax method.

\section{Results and Discussion}

Scientific literature and statistic studies showed that factors which loaded with less than three statements to be ignored, therefore factors loaded with more than three statements will be interpreted, while those loaded with less than three statements will be showed only.

\section{1 - Discussion of Open question for Faculty staff member Results:}

Factor analysis for the open question for faculty staff member (appendix 1 and Figure (4)) resulted in the following ten factors 


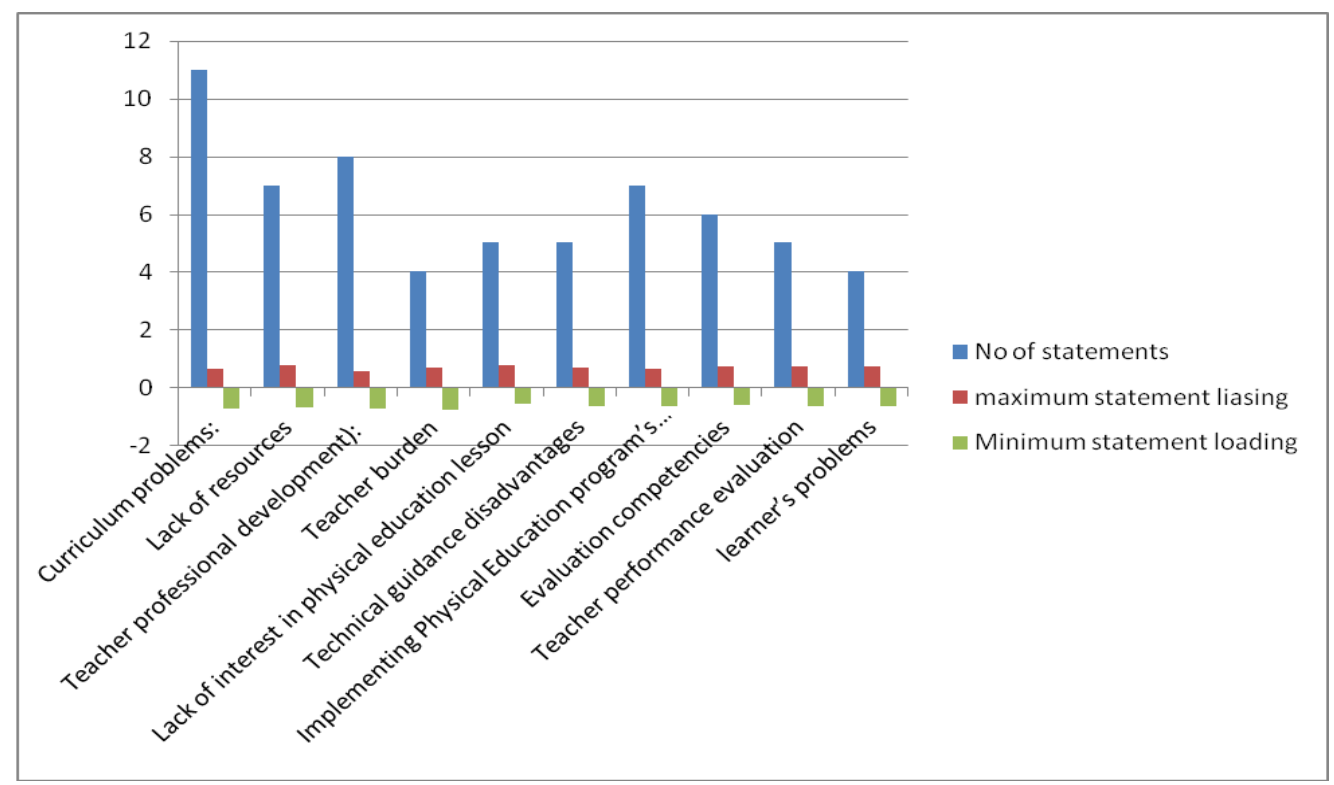

Figure (4) factors resulted from Faculty staff Factor matrix after rotation

- First factor: (curriculum problems): This factor statement is pure, with high loading values $(0.352$ to 0.734$)$. Researchers find this result logical as Lack of interest in sport education considering it as a waste of time. Some learners avoid participating in Physical Education lesson. Parents are not aware about sport activity practice importance. There is no diversity in evaluation methods. There is lack of recovery and preventive programs in curricula. Current curricula do not give interest to superior students, failure to observe learners attitudes, focusing on physical and skill aspects only, all are problems linked to curriculum and lead to poor physical and skill level of learners. This was confirmed by Nazik Sonble (1990) and argued by Makarem Abuhrjh and Saad Zaghloul (2000: 29-34), Essam El-Din and Badawy Abdel-Aal (2006, 165-168), Mervat Khafaja and Mustafa Sayeh (2007, 14 -16,72,73)

Mohammed Khamis, Naif Saada (2008, 395396) recommended the necessity to consider teachers opinion when building or developing curricula taking into account aspects of Physical Education curricula implementation. Abdullah Al-Jafari and Yousef Hagag (2008, 273) emphasized the need to work on school activities integration within curricula to contribute to formation and growth of integrated personality, and this agreed with recommendations of Mustafa Al-Sayeh , Mohamed El kerdany (2002: 270-271).

- Second factor: (lack of resources), this factor statements which has high loading (0.404-
0.748 ) is related to resources in terms of: Low funds for sports activity, Lack of maintenance and repair of tools and equipment in school, Teachers not encouraged to attend training and refereeing sessions in specialization, Safety and security factors not available in playgrounds, lack of technological tools that help in education process, Guiders numbers are in shortage in education directorates, Low salaries and weak incentives. This was argued by Essam Metwally and Badawy Abdel Aal 2006, 232-233), Mohammed Khamis and Nayef Saada (2008, 444-446). This also confirmed by results and recommendations of studies of Iman Salem (1991, 159-160) Randa Farouk (2007, 104), Makarem and Mohamed Saad 2000: 33- 37).

- Third factor : (teacher professional development): It can be noted that statements of this factor (with loading of $0.347-0.763$ ) deal with problems of teacher preparation, such as the contradiction between the academic study and practical reality; lack of innovation in lesson implementation; not using appropriate evaluation methods; non-allocation of time for free activity to develop learners tendencies; there is no card dedicated for evaluating physical education teacher's performance, and that curriculum does not encourage change and innovation; discourage training courses attendance, are of problems facing the teacher in his career.

This makes it difficult to evaluate the objectives of the curriculum as per quality standards, and this is indicated by the Makarem Abu Hrjh and 
Saad Zaghloul (2000, 28-34), that failure to encourage the teacher to attend training courses is due to the contrast between academic study and reality, and this was confirmed by the Quality Assurance Unit (2009) in the faculty in one of its self-reporting.

- Fourth factor: (teacher burden): It can be noted that the statements of this factor (with loading of 0.420-0.780) deal with the problems of assigning physical education teacher additional burden hinder performance of his duty, lack of awareness of other subjects teachers about the importance of physical education, the cancelling Physical Education lessons before examinations, lack of playgrounds in educational institutions, are from psychological and professional burdens facing physical education teacher in his work.

This was explained by Makarem abu Hrja and Saad Zaghloul (2000, 33-34) which in turn result inequality between physical education teachers and other subjects teachers.

- Fifth factor: (lack of interest in physical education lesson) Statements of this factor (with loading of (0.391-0.739) addressed lack of interest in studying physical education, which is represented in the lack of school administration interest in Physical Education, transferring of sports activity budget to other expenses types, and lack of incentives for high sports achievers, which lead to high rate of body distortions among school students. This argued by Makarem Abu hrjh and Saad Zaghloul (2000) (Makarem and Saad 2000: 33,34, 38), and confirmed by Nazik Sonble (1990) study results which indicated that lack of annual report objective is natural result of lack of school administration interest in physical education.

- Sixth factor: (technical guidance disadvantages): This factor statements (with loading of 0.402-0.687) associated with technical guidance disadvantages, where guider do not have capacity for innovation, creativity and innovation, guidance is formal rather than practical, low guider's scientific and technical level make him out of date, wide scope of schools supervision for guiders making it difficult to guide, guider decisions are not debated or discussed.
- Seventh factor (Implementing Physical Education program's difficulties): statements of this factor (with loading of 0.477-0.665) represent program implementation difficulties the including : poor sports awareness of school management, the inequality between physical education teacher and other teachers in rights, warehouses not valid to store sports equipment, there is no appropriate clothes changing rooms close to playground, lack of resources that help to implement integrated program, weak chances physical education teacher promotion, learner is not free to express himself and use his energies. This agrees with Mohammed Khamis and Nayef Saada (2008, 54-55).

- Eighth factor: (evaluation competencies): Statements in this factor (with loading of 0.4900.736) were about problems like: lack the other subjects teachers awareness of physical education importance, guider, teacher and learner do not contribute in curriculum planning, lack of teacher independence in his work are linked to teachers personal competencies, in addition to that guidance highlight problems and do not take decision to solve it is linked to evaluation competencies necessary for educational process' success. This explained by Bedor Al-Mutawa and Suheir Bediar (2006, 272-275), Samia Farghaly and Nadia Abdel Kader (2002, 66-68), Mohammed Khamis, Naif Saada (2008, 36-37), Kausar Kojak (1997, 138-140).

- Ninth factor : (Teacher performance evaluation): This factor statement (with loading of 0.481-0.728) dealt with teacher evaluation disadvantages like : confidential reports are based on personal relationships and courtesies, there is weakness in communication channels between guider and teacher, teacher does not have some specialization as his professional preparation is disproportionate to work requirements in some institutions, in addition guiders and teachers do not follow up the new in the field of profession, are all of the problems that lead to a lack of objectivity in evaluating teacher. This was indicated by Makarem Abu Hrjh and Saad Zaghloul (2000, 34-36), Bedor Al-Mutawa and Suheir Bedair (2006, 208, 217$218,274)$ explained profession competencies to be available in physical education teacher. Mustafa Sayeh (2001, 348-352) added the 
necessity to give correct knowledge and highly skilled the teacher as well as practical training, which puts teacher in the face of reality and that success factors of educational professional preparation lies in the teaching methods used.

- Tenth Factor (learner's problems), this factor statements (with loading of 0.376-0.700) addressed learner's problems, in spite of learner importance as the center of educational process, but curriculum activities does not meet learners needs, and not respond to learner requests about tools, no suitable conditions for activity practicing; which lead to poor health level of learners, Mustafa Sayeh (2001, 348-352) recommended that curricula activities to be rebuilt to suit learners needs.

\section{II- Discussion of first and second grades students' questionnaire results}

Factor analysis for First and second grades students' questionnaire (appendix 2 anf Figure 5 ) resulted in the following five factors

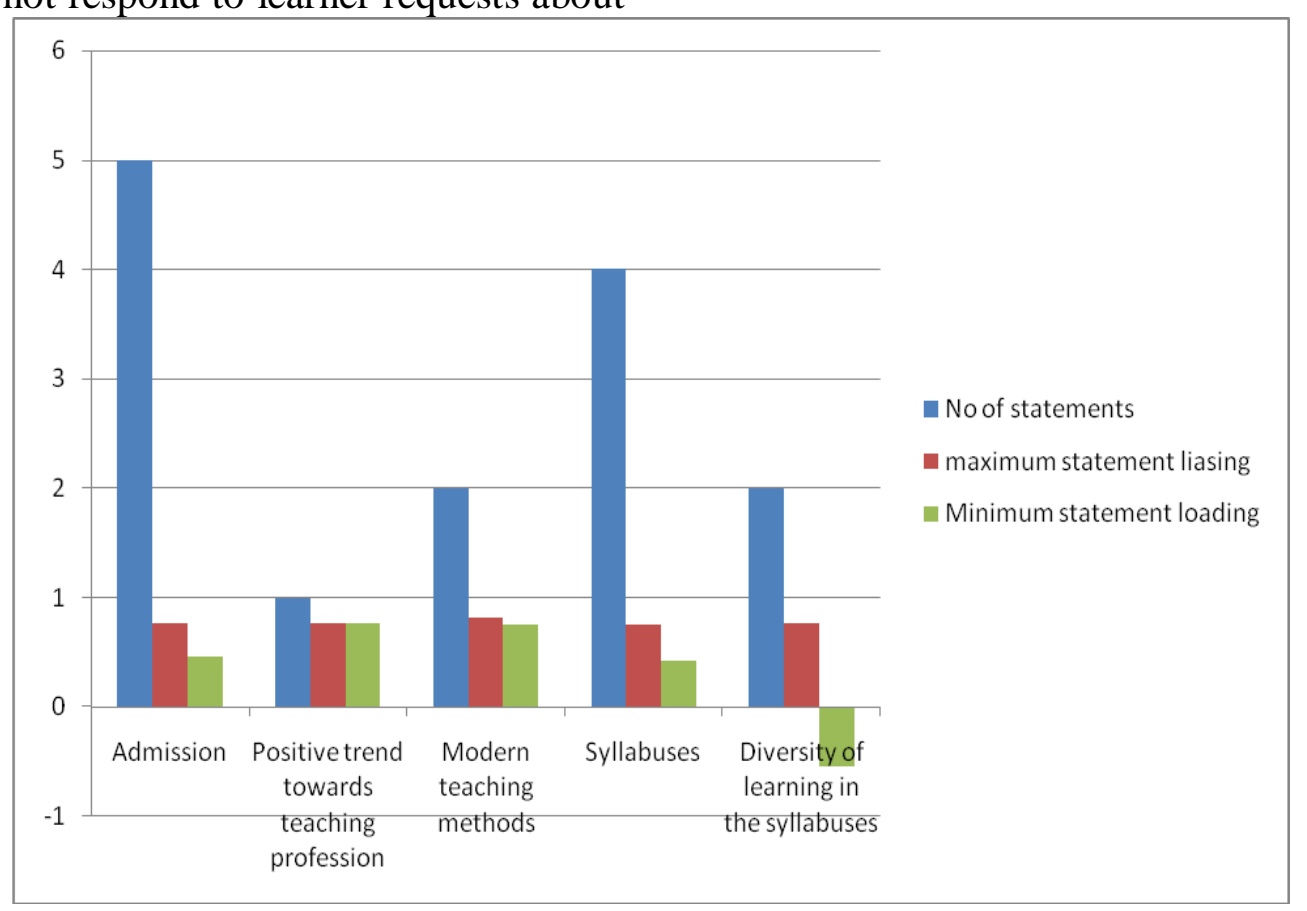

Figure (5) factors resulted from Preliminary phase students (first and second grades) Factor matrix after rotation

- First Factor (Admission): This factor questions (with loading of 0.458-0.762)are around Admission and appropriateness of acceptance tests (ability tests) to student level, whether student is satisfied with joining faculty, what physical fitness student gain by studying in preliminary phase. This is logical as whenever student enrolls in the faculty as per her desire, acceptance tests are appropriate for the level, the student is satisfied with faculty joining and be able to excel in her studies and gain many skills and experiences and benefit from courses taught. Aza Hamdy (1990 , 55) study emphasizes not to accept all who apply or graduate all who enroll, but must choose who possess the necessary qualifications for teaching profession, such as desire, practical and mental ability for this type of work. This is also in line with Mervat Khafaja and Mustafa Sayeh (2007, 177).
There is no doubt that in order to prepare good teacher, we must improve student selection, which will one day become a teacher bearing great responsibility, and this student that will be accepted in faculties of physical education must meet the conditions for acceptance in terms of personality traits and aptitudes, skills and abilities, values and attitudes. So it is a must to choose the best from who applied using standardized and objective acceptance tests (Mohamed Saad Zaghloul: 2000, 39)

- Second factor (positive trend towards teaching profession): Questions in this factor (with loading of 0.549-0.764) are about development the positive trend towards teaching profession through determining common errors for each activity and its correction methods, as well as set clear objectives and specified description for each syllabus, Syllabuses' content help student 
to self-learn through using variety of teaching and learning methods. This is considered logical, where study in preliminary phase (first - second grades) and syllabus which student study, teaching methods used in teaching these syllabuses, as well student study of various activities, with knowledge in performance manner and common mistakes and ways to correct it contribute to developing positive trend towards teaching profession. Marwa Mohamed Fathi (1994), Kamel Abdel-Majid et al (1994), and Jihan Hussein Hamdani (1995) confirmed necessity to study attitudes and tendencies towards profession, and to study factors affecting selection physical education profession, as well as authorizing physical education subject as main subject, making physical education teachers more positive in their attitudes towards the profession.

- Third Factor (modern teaching methods) All of this factor questions (with loading of 0.752 0.819) are around teaching methods and techniques in use while teaching syllabuses, and whether they are traditional or modern, do syllabuses have clear objectives and specific description, do syllabuses provide opportunities for expressing and innovation, and whether each activity determined motor skills performance proper criteria. Using new teaching methods help to learn all sports activities skills in the program. Afaf Abdel-Karim (1989, 116) confirm the need for diversification and innovation in teaching methods in order to achieve success in educational situations. This was confirmed by Omaima Hussein study (2005) and by Mustafa Al-Sayeh, M Fathy Elkerdany (2002, 270-271 ) study recommendations of need to develop teaching performance using modern teaching methods in theory and practice teaching. In the same time Quality Assurance Unit (2009) in the faculty also through its annual report suggested establishing laboratory of teaching methods to provide faculty students with all that is new and developing their teaching skills.

- Fourth factor (syllabuses): This factor questions (with loading of 0.429-0.755) is around syllabuses and whether they provide opportunity for team work, and whether they have clear objectives and specific description, and appropriateness of syllabuses' content and the number of lecturers to lectures time, Do syllabuses give the opportunity for expression and innovation. All these are consistent with the Mustafa Al-Sayeh et al (2002) study results where it revealed that some syllabuses do not give opportunity for learners to express their views, the study recommended the need to characterize faculty syllabuses as per university education quality concept

- Fifth Factor (diversity of learning in the syllabuses): These factor statements with high loading (0.53-0.761) are about faculty tests. Faculty tests by expressing student ability make her benefit from syllabuses in her preparation to teach physical education. Qassem Lezam et al (1993.17) argued that diversity in learning and use of teaching methods has greatest impact in successful education

III - Discussion of third and fourth grades students' questionnaire results

Factor analysis for third and fourth grades students' questionnaire (appendix 3 and Figure 6 ) resulted in the following eleven factors 


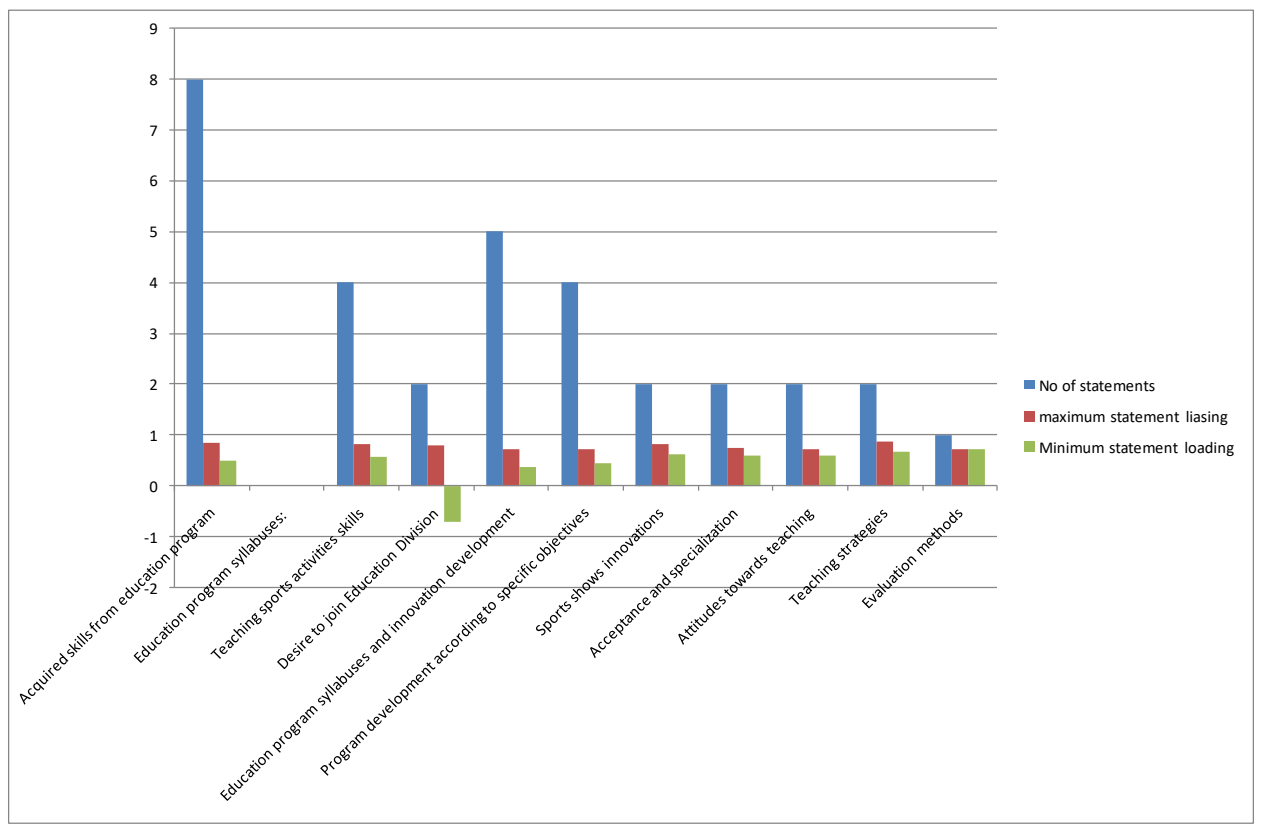

Figure (6)

Factors resulted from Specialization phase students (third and fourth grades - education section) Factor matrix after rotation

- First factor (acquired skills from education program): Questions of this factor (with loading of 0.499-0.851) are around the education program and its role in giving teaching skills and make physical measurements and tests, design cultural programs for technical and commerce education, and acquiring experience of using educational media and technology, ability to train scouts and acquire motor analysis skill of performance and identify the content of sports activities. It is clear from this that all questions is about education program and skills acquired by it; therefore researchers named this factor "acquired skills from education program". The education program is from faculty basic programs, which plays an important role in giving the student / teacher many skills that qualify her to work in teaching profession. This was confirmed by Bedor Al-Mutawa and Suheir Bedair (2006, 272-274), Makarem Abu Hrjh, and Saad Zaghloul $(2000,22)$ who argued that there is necessity to reconsider methods of physical education teacher preparation by focusing on programs of educational competencies.

- Second factor (Education program syllabuses): Questions of this factor (with loading of 0.4930.785 ) are mostly around syllabuses studied by student through education program and how they contribute to physical education teacher preparation, as well as sport culture gained by student through syllabuses studied in education division. As these syllabuses are taught using modern and unconventional teaching methods, and thus lead to student acquire lot of professional competencies required for teaching profession. Osama Kamel Rateb (1992, 5) argued that educational system ability to achieve its objectives depends to large extent on the type of teacher and what he possess from professional competencies. Kausar Kojak (1997, 138-140), Samia Farghaly and Nadia Abdul Qadir (2002, 65-66), Bedor Al-Mutawa and Suheir Bedair (2006, 273-274) agreed to this opinion.

- Third factor (teaching sports activities skills), This factor's questions (with loading of 0.4290.755 ) is about sports activity skills and the role of education program in using teaching skills that help to learn those skills through use and production of modern teaching methods and development of standards for proper functioning for motor skills. This can be considered logical, where we find that knowledge of teaching skills help to deliver sports activities content and gaining the ability to teach all sport skills and production modern teaching methods and identify each activity to correct performance standards help in teacher well preparation;, all this if she wish to enroll in education division. This is illustrated Samia Farghaly and Nadia Abdel Kader (2002 , 62,67). Each activity 
proper performance standards of motor skills and student/ teacher mastery of it relate to preparing education program for the student / teacher.

- Fourth factor (the desire to join Education Division): The questions here (with loading of 0.703-0.792) are around desire to enroll in education division, and acquisition of sports culture through this specialization and satisfaction for joining this specialization. The desire to join education division helps students to be satisfied with the division; which have the greatest impact in program contribution of culture preparation of the student. Azza Hamdy $(1990,55)$ recommended the necessity of teacher guidance for each individual to join the spatiality which integrate with his general abilities, inclinations and aptitudes. This is confirmed by faculty strategic objectives, represented in fifth objective (Faculty of physical education for girls, Alexandria, 2009) and illustrated by Mervat Khafaja and Mustafa Sayeh (2007, 182-185)

- Fifth factor (education program syllabuses and innovation development) This factor questions (with loading of 0.376-0.720)are about syllabuses and innovation development in the field of specialization or dealing with handicapped, as well as innovation in content development which achieve objects. It makes sense that the program syllabuses which are consistent in terminology and concepts will prepare the student/teacher for teaching physical education for handicapped and make them able to develop content to achieve their goals. A study in the annual report of Quality Assurance Unit (2009, study 4) emphasized on existence of deficiencies in girl scouts and scouts information, and the absence of a syllabus dedicated to handicapped, The development of program required associated with concepts agreement in the program, as well as syllabuses provide opportunity for creativity. This is illustrated Iglal Ibrahim, and Nadia Darwish (1994, 81-82) , Ahmed Alnagdy et al (2005, 332-335).

- Sixth factor (program development according to specific objectives), This factor questions (with loading of 0.629-0.822) are addressing program content development according to specific objectives as per age stages and their needs, contribute in program content development of different education types including technical education. This is natural as program content must achieve objectives set for it. Education program should help student in developing the content for various and different objectives (such as design recovery exercises commensurate with the age groups, design sports journal and school media content, developing content for different types of technical education). This is logical since the education program and syllabuses in it gives the student a chance to design magazines and be prepared for teaching of different categories. Asim Hammoudi, Mustafa Ahmed (2009) study recommended necessity of implementing programs in the form of training courses to perfect teachers in the areas of motor injury and cooperation with Department Health Sciences department in the implementation of these programs.

- Seventh Factor (Sports shows innovations): (7) questions loaded in this factor (with loading of 0.629-0.822), five of them already interpreted; the rest is about physical fitness, show innovation, performing parties. This is logical as acquisition of physical fitness in the preliminary stage makes student/teacher participate in sports shows $\mathrm{n}$ faculty, which gives her the ability to perform show or party. This falls within competencies gained by the student/teacher during her study in the faculty. This was confirmed by Ibrahim Abdel-Maksoud (1989, 213 214), Samia Farghaly and Nadia Abdel Kader (2002, 38 , 39), Mohammed Khamis, Nayef Saada (2008, 429 430). Quality assurance annual report (2009) refer to student inability to organize parties and festivals. Marwa Hamdy (2003, 138-139) study results indicated that through preparation of physical education teacher competencies list related to performing school parties

- Eighth Factor (Acceptance and specialization): (5) questions loaded on this factor (3) of them already explained (with loading of 0.590-0.737). The rest of questions address methods of acceptance in faculty and education section. Thus because appropriate method of acceptance in education division and its agreement with student desire to join the division make her acquire teaching ability to different educational 
stages. Therefore researchers in the opinion of developing accurate sound basis for student selection and passing psychological test among other tests, so it is possible to discover teaching profession talents within applicants for the division and have the desire to work in the profession to get advantage of them

Therefore students applying for education division must be characterized by qualities consistent with requirements of teaching profession, which is represented in many aspects, including physical, cognitive, skills, psychological, through standardized and objective acceptance tests. (Ali Rashid 1996, 15)

- Ninth factor - (attitudes towards teaching): Questions on this factor (with loading of 0.6030.727 ) are about preparation for the teaching profession and amending attitudes towards it. Since student desire to enroll in the faculty associated with faculty program contribution to amend her attitudes towards physical education profession. This were argued by Makarem Abu Hrjh, Saad Zaghloul (2000m 15-16) that physical education various activities work to achieve learner balanced total development as per his abilities, aptitudes, inclinations and motivations. Faculty's Quality Assurance Unit in its annual report (2009) highlighted that some faculty programs omit developing positive attitudes towards profession and team work.

- Tenth Factor (teaching strategies): Questions in this factor (with loading of 0.658-0.861) are about different teaching strategies for various educational stages. One of the basics of physical education teacher preparation during specialization phase in education section is to use different strategies in teaching education program syllabuses. This was confirmed by Samia Farghaly and Nadia Abdel-Kader (2002, 27-31, 36 -38 .138 -140), Nayef Saada and Mohammed Khamis $(2008,122)$,

The program and its multiple strategies assist in teacher preparation for the profession during her study in specialization phase. This was confirmed by Housnen \& Griffey $(1985,45-53)$ study which stated that physical education student/teacher or teacher use of teaching strategies depends on experiences gained during faculty study. Naif Saada and Mohammed Khamis $(2008,122)$ agreed with this statement

- Eleventh factor (evaluation methods): (5) questions loaded on this factor (with loading of 0.728) (4) of them already interpreted which have higher loads on other factors. The last question is about modern evaluation methods of how to use them in learning aspects; this due to that student/teacher use of modern evaluation methods in evaluating learning aspects is of the basics of teacher preparing. This is illustrated by Mustafa Al-Sayeh (2004, 185-186), Mohammed Khamis, Naif Saada (2008, 42). Faculty's quality assurance unit in its technical report (2009) confirmed student weak awareness of evaluation methods as development approach of educational process, the report has recommended the necessity of students training on developing evaluation methods.. This called researchers to name this factor "evaluation methods".

\section{IV- Discussion of Guiders and teachers' questionnaire results}

Factor analysis for Guiders and teachers' questionnaire (appendix 4 and Figure 7) resulted in the following ten accepted factors 


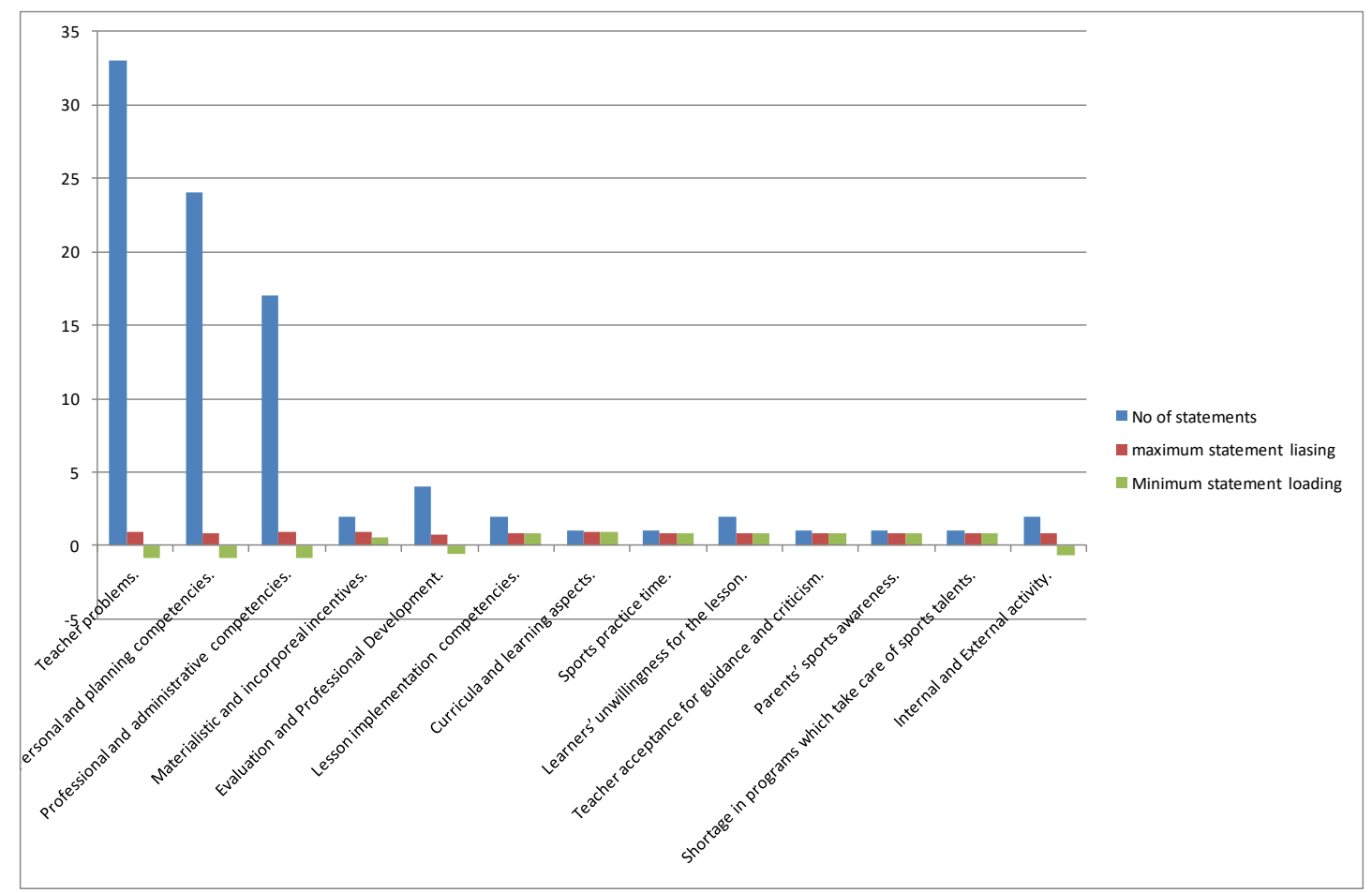

Figure (7) Guiders and teachers' Factor matrix after rotation

- First factor (teacher problems): This factor statements are pure, with high loads from (0.907, 0.303), and with dual loads as some are positive and others negative, some of this statements loaded also on other factor (2-10, and 13). Researchers have named this factor "teacher problems". Statements 1 to 6 this factor have been interpreted while interpreting faculty members factor analysis.

-Second Factor (personal and planning competencies), This factor statements are pure, with high loads from (-0.884 to 0.311$)$, with dual loads as some are positive and others negative. Some of these statements loaded also on other factor $(1,3,5,7,8,10)$. Researchers have named this factor " personal and planning competencies "

- Third factor (professional and administrative competencies): This factor statements are pure, with high loads from (0.929 to 0.303), and with dual loads as some are positive and others negative. Some of these statements loaded also on other factor $(1,2,4,7,9,11$ and 12), researchers have named this factor professional and administrative competencies "

-Fourth factor (materialistic and incorporeal incentives): This factor statements are pure, with high loads from (0.923 to 0.316), and with dual loads as some are positive and others negative, some of this statements loaded also on other factor (1, 2, and 7). researchers have named this factor " materialistic and incorporeal incentives "

- Fifth factor (Evaluation and Professional Development): The results reveal that this factor statements are pure, with high loads from $(0.767$ to 0.305), and with dual loads as some are positive and others negative. Some of this statements loaded also on other factor $(1,4,6,7$, and 8). Researchers have named this factor " Evaluation and Professional Development "

- Sixth factor (lesson implementation competencies): This factor's statements are pure, with high positive loads (0.88-0.883). Researchers have named this factor "Evaluation and Professional Development "

- Seventh Factor (curricula and learning aspects): The results reveal that these factor statements are pure, with high positive loads (0.947). This can be considered logical as faculty curricula must focus on all learning aspects (Cognitive, skill, emotional). This was argued by Bedor Al-Mutawa and Suheir Bedair (2006, 25-27), Samia Farghaly and Nadia Abdel Kader $(2002,96)$.

- Eighth Factor (sports practice time): The results reveal that this factor statements are pure, with high positive loads(0.878). This can be considered logical since enough time 
allocated to sports activity practice gives opportunity for learner to practice and train, and this what was argued by Samia Farghaly and Nadia Abdel Kader $(2002,225)$.

- Ninth factor (learners unwillingness for the lesson): ): This factor statements are pure, with high positive loads(0.808-0.854). Researchers have named this factor "learners unwillingness for the lesson "

- Tenth Factor (teacher acceptance for guidance and criticism), The results reveal that this factor statements are pure, with high positive loads (0.872). This can be considered logical because the teacher must have a willingness to accept Table (4) Research issues categorized as per quality academic standards fields

\begin{tabular}{|c|c|c|c|c|c|}
\hline \multirow[b]{2}{*}{ No. } & \multirow[b]{2}{*}{ Suggested issues } & \multicolumn{4}{|c|}{ quality academic standards fields } \\
\hline & & Education & $\begin{array}{l}\text { Scientific } \\
\text { research }\end{array}$ & $\begin{array}{l}\text { Community } \\
\text { service }\end{array}$ & $\begin{array}{l}\text { Administrative } \\
\text { and } \\
\text { professional } \\
\text { development }\end{array}$ \\
\hline & 1- Issues related to curriculum: & & & & \\
\hline 1 & $\begin{array}{l}\text { Studies to develop subjects curricula } \\
\text { as per integration approach, quality } \\
\text { and accreditation standards and as per } \\
\text { labor market. Needs. }\end{array}$ & / & & / & \\
\hline 2 & $\begin{array}{l}\text { Studies to analyze and evaluate } \\
\text { physical education curricula for } \\
\text { different educational stages. }\end{array}$ & 1 & / & & \\
\hline 3 & $\begin{array}{l}\text { Suggested programs especially for } \\
\text { talented pupils to improve and } \\
\text { promote their performance level. }\end{array}$ & 1 & 1 & 1 & \\
\hline 4 & $\begin{array}{l}\text { Proposed programs for development } \\
\text { of sporting activities curricula content } \\
\text { for various educational institutions. }\end{array}$ & 1 & & & / \\
\hline 5 & $\begin{array}{l}\text { Analytical studies of the current status } \\
\text { of physical education curricula } \\
\text { through following modern practices } \\
\text { methods. }\end{array}$ & 1 & / & & / \\
\hline 6 & $\begin{array}{l}\text { Programs in evaluating cognitive and } \\
\text { behavioral objectives for scout } \\
\text { curriculum fields for different } \\
\text { education stages. }\end{array}$ & 1 & / & & / \\
\hline 7 & $\begin{array}{l}\text { Special programs for free activity for } \\
\text { development learners' tendencies and } \\
\text { desires. }\end{array}$ & / & & & / \\
\hline
\end{tabular}

guidance and criticism in order to overcome weaknesses and problems may be faced by her. Makarem Abu Hrjh and Saad Zaghloul (2000, 52), indicated that teacher's failure to accept criticism is one of teacher deficiencies in personal and professional competencies, therefore, researchers named this factor " teacher acceptance for guidance and criticism"

In light of correlation arrived between opinions of Faculty staff, students, beneficiaries; researchers arrived to research topics for post graduate students. These topics are categorized as per quality academic standards (refer to table 4) 


\begin{tabular}{|c|c|c|c|c|c|}
\hline \multirow[b]{2}{*}{ No. } & \multirow[b]{2}{*}{ Suggested issues } & \multicolumn{4}{|c|}{ quality academic standards fields } \\
\hline & & Education & $\begin{array}{l}\text { Scientific } \\
\text { research }\end{array}$ & $\begin{array}{l}\text { Community } \\
\text { service }\end{array}$ & $\begin{array}{l}\text { Administrative } \\
\text { and } \\
\text { professional } \\
\text { development }\end{array}$ \\
\hline 8 & $\begin{array}{l}\text { Programs in measurement and } \\
\text { evaluation of sports activities to assess } \\
\text { learners' performance giving concern } \\
\text { to scientific methods. }\end{array}$ & / & / & & / \\
\hline 9 & $\begin{array}{l}\text { Proposed curricula for handicapped } \\
\text { and who are motor learnable } \\
\text { according to disability type. }\end{array}$ & / & / & / & \\
\hline 10 & $\begin{array}{l}\text { Development of standardized tests to } \\
\text { measure the cognitive aspect in } \\
\text { various sports activities. }\end{array}$ & & / & & / \\
\hline & 2- Issues related to teacher: & & & & \\
\hline 11 & $\begin{array}{l}\text { Studies in teachers' professional } \\
\text { preparation of commensurate with } \\
\text { actual reality and scientific and } \\
\text { technical development. }\end{array}$ & & / & I & / \\
\hline 12 & $\begin{array}{l}\text { Scientific studies in teachers' } \\
\text { academic preparation commensurate } \\
\text { with working requirements in } \\
\text { different educational institutions. }\end{array}$ & / & / & / & / \\
\hline 13 & $\begin{array}{l}\text { Studies in how to use new } \\
\text { technologies in physical education } \\
\text { teaching field, to refine and train } \\
\text { teacher in different aspects (academic } \\
\text { profession culture and personal) }\end{array}$ & / & & / & / \\
\hline 14 & $\begin{array}{l}\text { Studies in the professional, personal } \\
\text { competencies and social interaction } \\
\text { with students, colleagues and } \\
\text { superiors. competencies }\end{array}$ & / & & & / \\
\hline 15 & $\begin{array}{l}\text { Studies on development of positive } \\
\text { attitudes towards work and human } \\
\text { relations between teachers. }\end{array}$ & & & & / \\
\hline 16 & $\begin{array}{l}\text { Studies on innovation of new learning } \\
\text { means and methods through } \\
\text { identification of challenges facing the } \\
\text { community while taking advantage of } \\
\text { available opportunities. }\end{array}$ & / & / & / & \\
\hline 17 & $\begin{array}{l}\text { Studies in the qualifying physical } \\
\text { education teachers during the service } \\
\text { by programs (qyalyfying, enrichment, } \\
\text { recreational programs) in as per } \\
\text { quality standards. }\end{array}$ & / & / & & / \\
\hline
\end{tabular}




\begin{tabular}{|c|c|c|c|c|c|}
\hline \multirow[b]{2}{*}{ No. } & \multirow[b]{2}{*}{ Suggested issues } & \multicolumn{4}{|c|}{ quality academic standards fields } \\
\hline & & Education & $\begin{array}{l}\text { Scientific } \\
\text { research }\end{array}$ & $\begin{array}{l}\text { Community } \\
\text { service }\end{array}$ & $\begin{array}{l}\text { Administrative } \\
\text { and } \\
\text { professional } \\
\text { development }\end{array}$ \\
\hline 18 & $\begin{array}{l}\text { Studies in determining performance } \\
\text { competencies of physical education } \\
\text { teacher for various activities; analyze } \\
\text { and evaluate. }\end{array}$ & / & / & & / \\
\hline 19 & $\begin{array}{l}\text { Studies on physical education } \\
\text { teacher's sports cultural awareness e } \\
\text { to meet professional changes through } \\
\text { well-prepared programs. }\end{array}$ & 1 & 1 & & l \\
\hline 20 & $\begin{array}{l}\text { Develop proposed manual for physical } \\
\text { education teachers in different } \\
\text { educational institutions fits with era } \\
\text { modern trends. }\end{array}$ & / & / & & / \\
\hline 21 & $\begin{array}{l}\text { Studies to measure job satisfaction of } \\
\text { physical education teachers. }\end{array}$ & & / & & / \\
\hline 22 & $\begin{array}{l}\text { Studies to measure the stress } \\
\text { experienced by physical education } \\
\text { teachers in community and develop } \\
\text { suitable solutions. }\end{array}$ & & / & / & l \\
\hline 23 & $\begin{array}{l}\text { Proposed programs to develop } \\
\text { professional growth for physical } \\
\text { education teachers in school sports } \\
\text { activities and in light of recent trends. }\end{array}$ & & 1 & 1 & / \\
\hline 24 & $\begin{array}{l}\text { Studies in modernization of physical } \\
\text { education teacher preparation } \\
\text { programs in order to design Bachelor } \\
\text { of Physical Education for Girls at the } \\
\text { Alexandria University program in } \\
\text { light of contemporary trends and labor } \\
\text { market needs. }\end{array}$ & & / & / & / \\
\hline 25 & $\begin{array}{l}\text { Information technology and self- } \\
\text { preparation for physical education } \\
\text { teacher. }\end{array}$ & & / & & / \\
\hline 26 & $\begin{array}{l}\text { Proposal to develop practical } \\
\text { education in light of quality academic. }\end{array}$ & / & / & & / \\
\hline 27 & $\begin{array}{l}\text { Comparative studies of physical } \\
\text { education teacher preparation systems } \\
\text { in Arab Republic of Egypt and } \\
\text { advanced countries. }\end{array}$ & & / & / & / \\
\hline 28 & $\begin{array}{l}\text { Studies of the acceptance criteria in } \\
\text { different sections in the faculty. }\end{array}$ & / & / & & / \\
\hline
\end{tabular}




\begin{tabular}{|c|c|c|c|c|c|}
\hline \multirow[b]{2}{*}{ No. } & \multirow[b]{2}{*}{ Suggested issues } & \multicolumn{4}{|c|}{ quality academic standards fields } \\
\hline & & Education & $\begin{array}{l}\text { Scientific } \\
\text { research }\end{array}$ & $\begin{array}{l}\text { Community } \\
\text { service }\end{array}$ & $\begin{array}{l}\text { Administrative } \\
\text { and } \\
\text { professional } \\
\text { development }\end{array}$ \\
\hline 29 & $\begin{array}{l}\text { Programs to develop scientific } \\
\text { curricula for student/teacher } \\
\text { preparation in proportion to } \\
\text { community needs and the teaching } \\
\text { requirements in light of quality and } \\
\text { accreditation standards. }\end{array}$ & / & / & l & / \\
\hline \multirow[t]{2}{*}{30} & $\begin{array}{l}\text { Studies in how to develop positive } \\
\text { attitudes towards the profession of } \\
\text { physical education. }\end{array}$ & / & / & & \\
\hline & 3- Issues related to the guidance & & & & \\
\hline 31 & $\begin{array}{l}\text { Standardized studies on how guider } \\
\text { evaluate physical education teacher } \\
\text { performance in all aspects as per } \\
\text { quality standards. }\end{array}$ & & I & I & / \\
\hline 32 & $\begin{array}{l}\text { Studies to raise scientific and } \\
\text { technical level of physical education } \\
\text { guider to keep up with era changes. }\end{array}$ & & I & 1 & I \\
\hline 33 & $\begin{array}{l}\text { Studies for development of physical } \\
\text { education guider's professional } \\
\text { growth. }\end{array}$ & & T & & / \\
\hline 34 & $\begin{array}{l}\text { Studies in leadership behavior and } \\
\text { ability to innovative thinking using } \\
\text { latest modern technology. }\end{array}$ & & / & & / \\
\hline \multirow[t]{2}{*}{35} & $\begin{array}{l}\text { Studies on technical guidance role in } \\
\text { activation of performance quality } \\
\text { standards for physical education } \\
\text { teachers. }\end{array}$ & & / & / & \\
\hline & $\begin{array}{l}\text { 4- Issues related to school } \\
\text { administration: }\end{array}$ & & & & \\
\hline 36 & $\begin{array}{l}\text { Studies on how school management } \\
\text { assess physical education teacher, } \\
\text { according to scientific criteria with } \\
\text { regard to educational process. }\end{array}$ & I & I & & I \\
\hline 37 & $\begin{array}{l}\text { Developing programs in educational } \\
\text { information systems to identify } \\
\text { educational process reality to make } \\
\text { sound management decisions in the } \\
\text { field of school sport. }\end{array}$ & / & I & & / \\
\hline
\end{tabular}




\begin{tabular}{|c|c|c|c|c|c|}
\hline \multirow[b]{2}{*}{ No. } & \multirow[b]{2}{*}{ Suggested issues } & \multicolumn{4}{|c|}{ quality academic standards fields } \\
\hline & & Education & $\begin{array}{l}\text { Scientific } \\
\text { research }\end{array}$ & $\begin{array}{l}\text { Community } \\
\text { service }\end{array}$ & $\begin{array}{l}\text { Administrative } \\
\text { and } \\
\text { professional } \\
\text { development }\end{array}$ \\
\hline 38 & $\begin{array}{l}\text { Developing programs in management } \\
\text { development for educational leaders } \\
\text { commensurate with service } \\
\text { management nature and techniques. }\end{array}$ & & 1 & & / \\
\hline 39 & $\begin{array}{l}\text { Studies about media role importance } \\
\text { in the spread sports culture to raise } \\
\text { awareness of sports management at } \\
\text { educational institutions. }\end{array}$ & 1 & & & / \\
\hline 40 & $\begin{array}{l}\text { Analytical studies to demonstrate the } \\
\text { importance of physical education } \\
\text { practice in support national security in } \\
\text { Egyptian community. }\end{array}$ & & 1 & / & \\
\hline 41 & $\begin{array}{l}\text { Analytical studies to demonstrate the } \\
\text { importance of physical education } \\
\text { practice in development of national } \\
\text { character. }\end{array}$ & & 1 & / & \\
\hline & 5- Issues related to the learner: & & & & \\
\hline 42 & $\begin{array}{l}\text { Proposed studies to raise and improve } \\
\text { physical, skill and motor fitness and in } \\
\text { different educational stages. }\end{array}$ & 1 & 1 & I & \\
\hline 43 & $\begin{array}{l}\text { Development of preventive programs } \\
\text { to protect and compensate for what } \\
\text { learner expose from body distortions. }\end{array}$ & & 1 & / & \\
\hline 44 & $\begin{array}{l}\text { Development of standardized tests to } \\
\text { measure physical fitness level to } \\
\text { determine learners' physical condition } \\
\text { in light of modern technologies. }\end{array}$ & & 1 & / & \\
\hline 45 & $\begin{array}{l}\text { Studies about causes of learner } \\
\text { unwillingness for sports activities. }\end{array}$ & 1 & 1 & & \\
\hline 46 & $\begin{array}{l}\text { Development of tests and } \\
\text { measurements based on the scientific } \\
\text { basis of motor skills in all sports } \\
\text { activities to be an indicator of the } \\
\text { extent of progress and success to } \\
\text { achieve the objective goals. }\end{array}$ & 1 & / & & \\
\hline 47 & $\begin{array}{l}\text { Studies in motivating students to } \\
\text { practice sports activities and raise } \\
\text { motivation, needs and preferences. }\end{array}$ & 1 & 1 & l & \\
\hline
\end{tabular}




\begin{tabular}{|c|c|c|c|c|c|}
\hline \multirow[b]{2}{*}{ No. } & \multirow[b]{2}{*}{ Suggested issues } & \multicolumn{4}{|c|}{ quality academic standards fields } \\
\hline & & Education & $\begin{array}{l}\text { Scientific } \\
\text { research }\end{array}$ & $\begin{array}{l}\text { Community } \\
\text { service }\end{array}$ & $\begin{array}{l}\text { Administrative } \\
\text { and } \\
\text { professional } \\
\text { development }\end{array}$ \\
\hline 48 & $\begin{array}{l}\text { Studies in spreading sport cultural } \\
\text { awareness of the broad base of sports } \\
\text { practitioners of various sports } \\
\text { activities. }\end{array}$ & & & / & \\
\hline 49 & $\begin{array}{l}\text { Studies in the development of cultural } \\
\text { awareness within parents to be more } \\
\text { aware of sport importance and } \\
\text { therefore encouraging their children to } \\
\text { sport practice. }\end{array}$ & / & & 1 & \\
\hline \multirow[t]{2}{*}{50} & $\begin{array}{l}\text { Studies in learner evaluating in order } \\
\text { to promote and reward to increase } \\
\text { motivation for further learning. }\end{array}$ & / & / & & \\
\hline & 6- Issues related to resources & & & & \\
\hline 51 & $\begin{array}{l}\text { Studies in how to self-develop school } \\
\text { resources. }\end{array}$ & & & 1 & \\
\hline 52 & $\begin{array}{l}\text { Studies in modern technology which } \\
\text { help in improving motor skills } \\
\text { learning process for various sports } \\
\text { activities. }\end{array}$ & / & / & & \\
\hline 53 & $\begin{array}{l}\text { Studies in planning for the preparation } \\
\text { and production of well prepared } \\
\text { teaching aids have legal status for all } \\
\text { sports activities and take into account } \\
\text { safety and security factors to increase } \\
\text { the of learners thinking ability.. }\end{array}$ & / & / & & \\
\hline 54 & $\begin{array}{l}\text { Assess education efficiency of using } \\
\text { technological means. }\end{array}$ & 1 & / & & \\
\hline \multirow[t]{2}{*}{55} & $\begin{array}{l}\text { Completion of an electronic } \\
\text { achievement file to evaluate } \\
\text { educational process in various sports } \\
\text { activities. }\end{array}$ & 1 & / & & \\
\hline & $\begin{array}{l}\text { 7- Issues related to teacher teaching } \\
\text { skills: }\end{array}$ & & & & \\
\hline 56 & $\begin{array}{l}\text { Studies in developing teaching skills } \\
\text { for student/teacher in light of quality } \\
\text { standards and accreditation. }\end{array}$ & / & / & & / \\
\hline 57 & $\begin{array}{l}\text { Studies on the ability to innovate in } \\
\text { physical education lesson using non- } \\
\text { traditional means and methods. }\end{array}$ & / & & & \\
\hline
\end{tabular}




\begin{tabular}{|c|c|c|c|c|c|}
\hline \multirow[b]{2}{*}{ No. } & \multirow[b]{2}{*}{ Suggested issues } & \multicolumn{4}{|c|}{ quality academic standards fields } \\
\hline & & Education & $\begin{array}{l}\text { Scientific } \\
\text { research }\end{array}$ & $\begin{array}{l}\text { Community } \\
\text { service }\end{array}$ & $\begin{array}{l}\text { Administrative } \\
\text { and } \\
\text { professional } \\
\text { development }\end{array}$ \\
\hline 58 & $\begin{array}{l}\text { Using educational modules in skills } \\
\text { learning (in each activity). }\end{array}$ & I & 1 & & \\
\hline 59 & $\begin{array}{l}\text { Design electronic syllabuses for } \\
\text { Faculty of Physical Education for } \\
\text { Girls in Alexandria in the light of } \\
\text { quality and accreditation standards. }\end{array}$ & 1 & / & & \\
\hline 60 & $\begin{array}{l}\text { Studies in } \\
\text { student/teacher scouting information. }\end{array}$ & 1 & & & \\
\hline 61 & $\begin{array}{l}\text { Studies in how to self-discover and } \\
\text { develop field training student. }\end{array}$ & 1 & & & \\
\hline 62 & $\begin{array}{l}\text { Studies for the qualifying of the } \\
\text { student / teacher preparation programs } \\
\text { for Scouts and Guides. }\end{array}$ & 1 & & & \\
\hline 63 & $\begin{array}{l}\text { Determining teaching skills of } \\
\text { physical education teacher in various } \\
\text { sports activities. }\end{array}$ & / & I & & / \\
\hline 64 & $\begin{array}{l}\text { Determine teaching skills of student / } \\
\text { teacher in various sports activities. }\end{array}$ & 1 & I & I & \\
\hline 65 & $\begin{array}{l}\text { Studies in the field of physical } \\
\text { education teacher competencies in } \\
\text { light of era requirements. }\end{array}$ & $1 /$ & 1 & & \\
\hline 66 & $\begin{array}{l}\text { The effectiveness of integrated } \\
\text { educational media in various sports } \\
\text { activities education. }\end{array}$ & 1 & I & & \\
\hline 67 & $\begin{array}{l}\text { Use of integrated educational media to } \\
\text { improve skill level in various sports } \\
\text { activities. }\end{array}$ & $1 /$ & 1 & & \\
\hline
\end{tabular}




\section{Conclusions:}

Researchers can conclude 39 factors from the results as in figure (8)

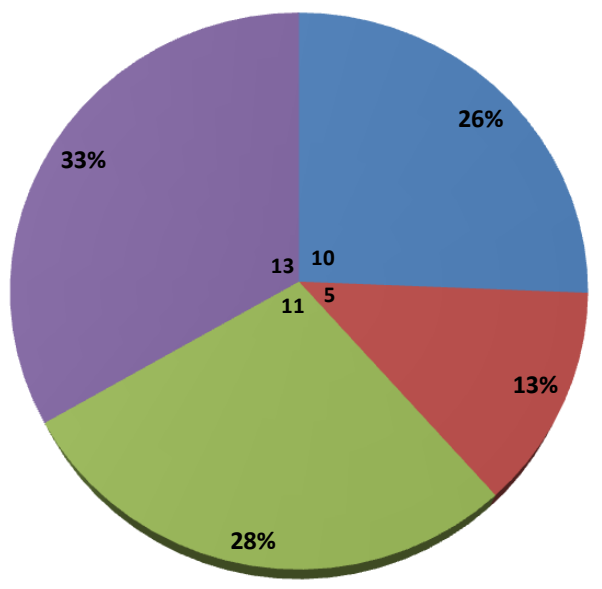
preliminary phase studen

Figure (8) Factors resulted from various sample categories

I - Open question for faculty staff members resulted in ten factors :

1- Curriculum problems:

2- Lack of resources

3- Teacher professional development

4- Teacher burden

5- Lack of interest in physical education lesson

6- Technical guidance disadvantages

7- Implementing Physical Education program's difficulties

8- Evaluation competencies

9- Teacher performance evaluation

10- learner's problems

II - Analyses of preliminary phase students (first and second grades) form resulted in fife factors:

1- Admission

2- Positive trend towards teaching profession

3- Modern teaching methods

4- Syllabuses

5- Diversity of learning in the syllabuses

III - Analysis of specialized phase students (Third and fourth grades) form resulted in 11 factors:

1- Acquired skills from education program

2- Education program syllabuses:

3- Teaching sports activities skills

4- Desire to join Education Division
5- Education program syllabuses and innovation development

6- Program development according to specific objectives

7- Sports shows innovations

8- Acceptance and specialization

9- Attitudes towards teaching

10- Teaching strategies

11- Evaluation methods

IV- Analyses of physical education' guiders/teachers form resulted in $\mathbf{1 3}$ factors:

1- Teacher problems.

2- Personal and planning competencies.

3- Professional and administrative competencies.

4- Materialistic and incorporeal incentives.

5- Evaluation and Professional Development.

6- Lesson implementation competencies.

7- Curricula and learning aspects.

8- Sports practice time.

9- Learners' unwillingness for the lesson.

10-Teacher acceptance for guidance and criticism.

11- Parents' sports awareness.

12-Shortage in programs which take care of sports talents.

13- Internal and External activity.

In conclusion researchers put these determined topics in research plan, it has been authorized as research plan for department of curricula and physical education teaching 
methods in its council meeting no (3) dated October $19^{\text {th }}$, 2009, It has been admitted to faculty vice-dean.

\section{Recommendations:}

In light of the research results, researchers recommend the following:

1- Publish this research to scientific departments in the faculty (Sports
Training and Motor Sciences, Recreation, Sports Management, Health Sciences, and Educational, Psychological and Social science)

2- Updating research topics in the plan as per total quality standards and contemporary trends 


\section{References}

Afaf Abdel-Karim (1989): Methods of teaching in physical education and sports , Maaref press, Alexandria. (in Arabic)

Ahmed El-Nagdy, Ali Rashid, Mona Abdel Hady(2005): Teaching science in the modern world (modern trends of science education in the light of international standards and thinking development and Lebanese theory), Dar ElFekr AlArabi, Cairo, (in Arabic).

Alaa Eddin Ibrahim, Hany Abdel-Moneim Said(2007): Problems of implementing Physical Education curriculum in the pre-university levels of education, Journal of Education, Sports, Volume (40), number (76 a), Faculty of Physical Education for Men, Zagazig University. (in Arabic)

Ali Ahmed Madkour (1998): Education curricula founded and its applications, Dar ELfekr, Cairo,. (in Arabic)

Amin Farouk Fahmy (2004): systemic approach and total quality control and management in the education system, Fourth Arab Conference on systemic approach in teaching and learning, Science, Regional UNESCO Education Development Center Office in Cairo, Ain Shams University, 3 to 4 April 2004. (in Arabic)

Angorla Scott : School Physical Education The United State, Issuse and Problems The British Journal of Physical Education, 2002 .

Arlen Gory Blix : Occupational Stress Among University - Teachers, Education Research, V. (36), N-(2) Etal, 1994.

Asim Saber Hammoudi, Mustafa Ibrahim Ahmed: Training program for physical education teachers for most common aid motor injuries among students of primary education, scientific journal for Science Physical Education and Sports, issue 13 September, Faculty of Physical Education, Mansoura University. (in Arabic)

Ayman Ali EL Shaeer (1999): professional stresses on physical education teacher and their relationship to professional consensus, Master Thesis, Faculty of Physical Education for men, Zagazig University. (in Arabic)

Azza Hamdy (1990): Analytical study of students tendencies in Faculty of Physical Education in Alexandria towards basketball, Journal of theories and applications, Faculty of Physical Education for Men, Alexandria University, vol. 8 page 55. (in Arabic)

Bedor Al-Mutawa, Suheir Bedair (2006): physical education and its curricula and teaching methods, Alketab publishing center, Cairo. (in Arabic)

Didi Griffioen (2012): 'Good research' within professional higher education institutes - the criteria of lecturers, Paper for the Onderwijs Research, Dagen Wageningen, June 20, 21 and 22 ,

Amsterdam University of Applied Sciences

Douthitt, Vicki Harvey Mark.L : Exercise Counseling - How Physical Education Can Help , Journal of Physical Education, Recreation and Dance , V.(66) , N(5) ,p(31-35) ,May-Jun, 1995 .

Ehab Abdul Halim Abdullah (2007): an analytical study to the problems of physical education and school sport, Master Thesis, Faculty of physical Education for men, Helwan University. (in Arabic)

Enayat Mohamed Farag (1998): Approaches and methods of teaching physical education Cairo, 1998. (in Arabic) 
Essam El-Din MH, Badawi Abdel Aal (2006): Methods of teaching physical education between theory and practice, to Wafaa printing and publishing, Alexandria. (in Arabic)

Faculty of Physical Education for Girls, Alexandria University (2009): goals and strategic objectives 2009-2013. (in Arabic)

Ghalib Alfrehat Abd al-moety (2008): Educational issues, studies and research in contemporary educational affairs, $1^{\text {st }}$ ed., AlAzmna, Amman (in Arabic)

Hassan Hussein Beblawi, Rushdi Ahmed Teima (2008): Total quality in education between excellence indicators and accreditation standards, foundations and applications, 2nd ed., Masira publication, distribution and printing, Amman (in Arabic)

Hassan Shehata, Fawzia Aba Al-Khail (2000): University Teaching Evaluation, Arab Gulf (ressala), number (78) Available: www.abegs.org (in Arabic)

Ibrahim Abdel-Maksoud (1989): Management and administration in physical education and sports, $3^{\text {rd }}$ ed., Alfania press, Alexandria. (in Arabic)

Iglal Mohamed Ibrahim, Nadia Mohammed(1994): modern creative dance, Cairo. (in Arabic)

Iman hassan Alharony, Kausar Abdul Majid El Sayed (2003): The impact physical education problems and its relationship to competencies for Physical Education teachers, Physical Education Research, Vol. (25), issue (60Benin Faculty of Physical Education for men, Zagazig University. (in Arabic)

Iman Mahmoud Sharif (2007): development of motor expression curriculum at the Faculty of Physical Education for Girls in Alexandria in the light of systemic approach, unpublished Ph.D. thesis, Faculty of Physical Education for Girls, Alexandria University. (in Arabic)

Iman Mohamed Abdullah (2004): An analytical study of physical education curricula objectives in basic education Arab Republic of Egypt. (in Arabic)

Iman Muhammad Sadiq (1995): a study to identify causes of disappearance of sport exercise shows from $2^{\text {nd }}$ Episode schools for basic education in Alexandria(in Arabic)

Iman Salem Mahfouz (1991): the role of technical guidance in achieving adequacy of physical education teacher, unpublished Ph.D. thesis, Faculty of Physical Education for Girls, Alexandria University. (in Arabic)

Iqbal Kamel Mahmoud et al (1998): The reality of school physical education in Egypt and some Arab countries, Scientific Conference: Sport and Development of Arab community and the requirements of the twenty-first century, Faculty of Physical Education for Girls, Helwan University. (in Arabic)

Jeane, Kentel : Using Technology to Enhance your Physical Education Program, Journal Indiana, Polis LTD.12(2), Fep, 1996 .

Jihan Hussein Hamdani (1995): Unwillingness of physical education graduates for work in teaching profession, Master Thesis, Faculty of Physical Education for Girls, Cairo. (in Arabic)

Kausar Hussain Kojak (2001): New trends in curricula and teaching methods, $2^{\text {nd }}$ ed., Alem Ekotb, Cairo. (in Arabic)

Lund,Mark : An Ableta, Review, Pathways : The Ontario- Journal of Outdoor Education , V.(9), N.(6), P.(33-34), Jan- Feb , 1998 .

Lynn D, Housnen \& David C., Griffey : Differences in Planning and Interactive Decision Making Between Experienced and inexperienced teacher, Research Quarterly for Exercise and sport, v56 n1 p45-53) Mar 1985/ 
Magdy Hussein Mahmoud Sadek (1995): An analytical study of reality of physical education at the primary school in Sharkia governorate, Ph.D. thesis, Faculty of Physical Education, Zagazig University. (in Arabic)

Mahmoud Abo Eleinin (1990): Issues facing professional physical education teacher in high schools in Giza, Scientific journal of Physical Education and Sports, Faculty of Physical Education for men, Cairo, No. 5, January 1990. (in Arabic)

Mahmoud Sami Abdel-Rahman (1993): The problems of implementation developed curriculum of the high school Physical Education, Master Thesis, Faculty of Physical Education for men in Cairo, Helwan University. (in Arabic)

Makarem Helmy Abu Hrjh, Mohamed Saad Zaghloul (2000): Problems of school physical education curricula, "diagnosis and treatment", Al Ketab Publishing, Cairo. (in Arabic)

Marwa Hamdi Elsayed (2003): Development of some of competencies associated with school parties for physical education teacher for girls, Unpublished Master Thesis, Faculty of Physical Education for Girls, Alexandria University. (in Arabic)

Marwa Mohamed Fathy (1994): A Study of the phenomenon of dropping out of the profession of teaching physical education, Journal of Sports Science and Arts, Volume VI, Issue 1, Helwan University. (in Arabic)

Melny chuk ,Nancy : Toward Understanding the Liver World of Physical Education Teacher in Curriculum Implemantation ,ph .Dunirrsity of Allgeraa, Canada , 1990 .

Mervat Ali Khafaja, Mustafa Mohammad Sayeh (2007): Introduction to Methods of Teaching Physical Education, $1^{\text {st }}$ addition, Mahy publication and distribution, computer services, Alexandria. (in Arabic)

Mohamed Sabry-Hout, Nahed Adly Shazly (2007): Education and Development, $1^{\text {st }}$ addition, the Anglo-Egyptian Library, Cairo. (in Arabic)

Mohammed Elsayed Hassouna(2003).: Educational research and development, Education magazine, issue (1) year 54, Cairo. (in Arabic)

Mohammed Khamis Abu namera, Nayef Saada (2008): physical education and teaching methods, United Arab Company for Marketing and Supply in cooperation with Al Quds Open University, Cairo. (in Arabic)

Mourad Saleh Zeidan (1997): professional pressures faced by pre-university teacher, Journal of the Faculty of Education, No. (29), College of Education, Zagazig University. (in Arabic)

Mustafa Al-Sayeh (2001): Technological competencies areas to prepare student / teacher in faculties of physical education, Journal of theories and applications, Faculty of Physical Education for men, Alexandria University, vol. 43 p 348-352. (in Arabic)

Mustafa Al-Sayeh, Mohamed Fathi Kerdany (2002): Practical education constraints for students / teachers of Faculty of Physical Education for Men , Alexandria, Journal of theories and applications, Faculty of Physical Education for Men, Alexandria University, vol. 44 p 270-271. (in Arabic)

National Authority for Quality Assurance and accreditation (2010): academic standards for total quality, available http://www.naqaae.eg/ (in Arabic)

Nazik Mustafa Sonble (1990): School management and technical guidance obstacles in field training, Faculty of Physical Education for Girls in Alexandria, Journal of 
theories and applications, Faculty of Physical Education for Men, Alexandria University, vol. 6 p. 8. (in Arabic)

Omaima Hassanein Mohamed Hegazy (2005): Diversity of teaching methods and their impact on learning some gymnastics skills and growth aspects for kindergarten children, published scientific production, Journal of Sports Science and Arts, Faculty of Physical Education for Girls, Cairo, 2005. (in Arabic)

Osama Kamel Rateb (1992): Child motor education, Dar ElFekr AlArabi, Cairo. (in Arabic)

Qasim Lezam et al (1993): Impact of some teaching methods in invested time in physical education in secondary schools, Journal of Physical Education, vol. II, Faculty of Physical Education, Baghdad. (in Arabic)

Quality assurance and accreditation unit, Faculty of physical education for girls(2009) Technical report of first phase of project ongoing development project and qualification and accreditation in the period from 2/4/2009 until 30/6/2009. (in Arabic)

Randa Farouk Askar (2007): the effectiveness of a proposed program for professional growth development for physical education teacher in motor expression in light of contemporary trends, unpublished Ph.D. thesis, Faculty of Physical Education for Girls, Alexandria University. (in Arabic)

Rushdi Ahmed Teima, Mohammed bin Suleiman Albandary (2008): Faculties of Education development between accreditation standards and total quality indicators in education between, 2nd ed., Masira publication, distribution and printing, Amman. (in Arabic)

Said Khalil El Shahed(1992): Problems facing the achievement of the objectives of the developed curricula for physical education in middle school, published research future vision of school sports conference, faculty of Physical Education for men, Alexandria university(in Arabic)

Samia Farghaly Mansour, Nadia Mohamed Abdel-Kader(2002): teaching and training in the field of Physical Education, Dar ELhikma, Alexandria. (in Arabic)

Sawsan Shaker, Mohammed Awad Alzyadat (2008): Quality in education, applied studies, $1^{\text {st }}$ ed., Safa House for Publishing and Distribution, Amman. (in Arabic)

Suhair Mustafa Almohandes(1991): A study of some variables related to the exercise of handicaps students in sports activity, Third Scientific Conference, future vision of the curriculum in the Arab world, Alexandria, Volume II, The Egyptian Association for Curricula and teaching methods, 4 to 6 August 1991. (in Arabic)

Susan A. C apel : Anxieties of Beginning Physical Education Teachers, Educational Research , V.(35),N.(3), 1993.

University of oxford (2008): strategic Plan 2008-9 To 2012-13, university of oxford, UK.

Wafaa Ali Elsaify (2002): Study student problems of practical education in training schools, Journal of Sports Science and Arts, Vol (17), Faculty of Physical Education for girls, Helwan University. (in Arabic). 